\title{
Impact of Sectoral Growth on the Economic Development of Bangladesh: An Experimental Study
}

\author{
Md. Shakhaowat Hossin* Md. Alamin Miah \\ Department of Finance and Banking, Begum Rokeya University, Rangpur, Bangladesh
}

\begin{abstract}
The study investigates the impact of sectoral growth on the economic development of Bangladesh. It has been accomplished from the viewpoint of financial intermediaries as well as real estate, renting and business activities sectors. The secondary data, for the period fiscal year (FY) 1995-1996 to the fiscal year (FY) 2018-2019, has been used to perform the analysis. The dependent variable in this study is the gross domestic product (GDP) representing the development status of the economy of Bangladesh. The independent variables- monetary intermediation (banks) sector (MIS), insurance sector (IS), other financial auxiliaries sector (FAS), real estate, renting and business activity sector (RBS) - have been used to show the relationship with GDP. A Multiple regression analysis has been used to develop the relationship. Besides, the coefficient of determination shows $70.2 \%$ of the variance in GDP can be predicted from the independent variables. If other independent variables are incorporated in the model, $63.6 \%$ of the variation in the dependent variable (GDP) can be explained by the independent variables, which is observed by adjusted R-square value. In the analysis, it has been found a considerable effect of monetary intermediation (banks) sector (MIS), insurance sector (IS), other financial auxiliaries sector (FAS), real estate renting and business activity sector (RBS) on GDP of Bangladesh. Finally, application of the outcome of this study will be effective only to the economy of Bangladesh.
\end{abstract}

Keywords: GDP, Monetary Intermediation, Correlation, Regression, Financial Auxiliaries sector (FAS), Analysis of Variance (ANOVA).

DOI: $10.7176 /$ RJFA/11-14-09

Publication date:July $31^{\text {st }} 2020$

\section{Introduction}

GDP is a very strong measure to gauge the economic health of a country and it reflects the total of the production of a country and as such comprises all purchases of goods and services produced by a country and services used by individuals, firms, foreigners and the governing bodies. It is used as an indicator by almost all the governments and economic decision-makers for planning and policy formulation. It enables one to judge whether the economy is contracting or expanding, whether it needs a boost or restraint, and if a threat such as a recession or inflation looms on the horizon. When government officials plan for the future, they consider the various economic sectors' contribution to the GDP. The volume of GDP is the sum of value-added, measured at constant prices, by households, government, and industries operating in the economy. GDP accounts for all domestic production, regardless of whether the income accrues to domestic or foreign institutions. The Organization for Economic Cooperation and Development (OECD), in a report released in November 2012, has also forecasted major shifts in global GDP by the year 2060. The Gross Domestic Product in the country like Bangladesh is experiencing a faster rate of growth in recent years. With regards to the composition of GDP, the percentage shares of various sectors have largely changed. The percentage share of agriculture in the total GDP has declined, on the contrary, the percentage share of services in the GDP is rising faster. With this shift, our economy which was considered, by and large, to be agriculture-based but with the opening up of the economy post-economic reforms of 1991, has become predominantly services-based with services accounting for $44.60 \%$ of the GDP and employing $35.70 \%$ of the population whereas agriculture accounts for $17.39 \%$ of GDP and employs $47.20 \%$ of the population and manufacturing and industry accounting for $25.75 \%$ of GDP and employing $24.70 \%$ of the population. Bangladesh Gross Domestic Product (GDP) is set to grow by $8.13 \%$ - the highest ever in the country's economic history- in the fiscal year (2018-19). Besides, the per capita income in the country is also set to grow to $\$ 1,909$.

\section{Review of Literature:}

A plethora of empirical studies have tested the relationship between financial intermediation and economic growth since the work of Goldsmith (1969). Using data from 35 countries between 1860 and 1963 he examined the correlation between financial intermediation and economic growth and argued that rough parallelism can be observed between economic and financial development if periods of several decades are considered.

Mckinnon (1973) in his study argued that there is a complementary relationship between physical capital and money that is reflected in money demand. This complementary relationship according to Mckinnon (1973) links the demand for money directly with the process of physical capital accumulation mainly because the conditions of money supply have a first-order impact on the decision to save and invest.

Debt intermediary hypothesis was proposed by Shaw (1973) which states that expanded financial 
intermediation between the savers and investors resulting from financial liberalization (higher real interest rates) and development increases the incentive to save and invest thereby stimulating investments due to an increase in the supply of credit and it also raises the average efficiency of investment.

Greenwood and Jovanovich (1990) stressed the informational role of financial intermediation in an endogenous growth model and argued that its role is crucially related to productivity growth of capital.

Bencivenga and Smith (1991) stressed that through its reduction of liquidity risks, in a related study, efficient financial intermediation stimulates savers to hold their wealth increasingly in productive assets, contributing to productive investments and growth.

Nissanke (1991) examined the structural impediments to savings mobilization and financial intermediation as including imperfect information and risk. She opined that as polices are introduced to encourage capital markets in developing countries, the improvement in banking institutions operation should be given due attention so that the economies could eventually benefit from the advantages of both bank-based and non-bank based finance.

Jayaratne and Strathan (1996) affirmed that financial development impacts positively on economic growth but with a clause that there is an improvement in the quality of bank lending. Using the bank deregulation reform in the US as a case study, it was established that the rate of real, per-capita growth in income increased significantly.

Levine (1997) followed the same line of thought but stressed the importance of stock markets in stimulating the financing of investment in less liquid investment projects, as well as the diversification of portfolio risk.

Odedokun (1998) emphasized that even though financial intermediation promotes economic growth, the growth-promoting effects are more pronounced in low-income countries. The strong positive relationship that manifested between financial intermediation and economic growth, the study established that the impact of financial intermediation is at par with export growth and capital formation.

Rajan and Zingales (1998) study sought to establish the impact of financial development on industry-specific growth. This necessitated a cross-country, cross-industry study. The primary hypothesis was, "industries that are more dependent on external financing will have relatively higher growth rates in countries that have a more developed financial market." The study asserts that financial development enhances growth in indirect ways.

Demirgue-Kunt and Maksimovic (1998) carried out a firm level-based study to justify their assertion concerning the relationship between finance and economic growth. This study shows that a developed financial system and legal system stimulates growth.

Levine, Loayza, and Beck (2000) changed the face of the argument on the relationship between financial intermediation and economic growth. This study seeks to establish the impact of the endogenous component of financial intermediation on economic growth.

Romeo-Avila (2007) also confirms the positive impact of finance on growth. He investigates the relationship between finance and growth, with emphasis on the effect of financial deregulation and banking law harmonization on economic growth in the European Union.

Rexiang and Rathanasiri (2011) examined whether financial intermediation leads to economic growth in a small open economy of Sri Lanka using time series macro data for the period 1977-2008. The findings of the study revealed that financial intermediation impact on economic growth in the long run but the relationship is not strong.

Shittu (2012) examine the impact of financial intermediation on economic growth in Nigeria. Time series data from 1970 to 2010 were used and were gathered from the CBN publications. For the analysis, the unit root test and co-integration test were done accordingly and the error correction model was estimated using the EngleGranger technique. The study established that financial intermediation has a significant impact on economic growth in Nigeria.

Peia and Roszbach (2013) re-examined the empirical relationship between financial development and economic growth in 26 countries. It is concluded that the leading role of financial intermediation in industrialized countries appears to vanish when we consider a period in which the financial sector has developed extensively.

Onodugo, Kalu and Anowor (2013) studied financial intermediation and private sector investment in Nigeria. The results showed that three out of the five coefficients are statistically significant at 5\% level. CEPS and PLR confirmed to the theoretically expected signs, while FS/RGDP, RGDP and DUM did not. Heteroscedasticity test carried out suggests that OLS assumption of constant variances overtime was not violated.

Uremadu, Nwokocha and Duru-Uremadu (2017) examined the effect of financial intermediation and government regulations on financial deepening and growth in Nigeria using time series data and OLS regression methodology. His findings showed that government bank regulations proxy by total balances with the central bank leads financial deepening in Nigeria.

Arabi (2014) employed the Johansen approach to cointegration and vector error correction model to examine the dynamic relationship between economic growth and financial development in Sudan over the period 1970 to 2012. The result indicates that a long-run co-integration exists between financial development and economic growth.

Madichie et al. (2014) investigated the relationship and direction of causality between financial development and economic growth in Nigeria. They applied error correction model and pairwise Granger causality test on four 
data series, namely: real gross domestic product, financial development, liquidity ratio and interest rate covering the period of 1986 to 2012 .

Hossin (2020) analysed the relationship among interest rate reforms, financial development and economic growth of Bangladesh by using a financial deepening model and a simple trivariate causality model. The inference of this study was that a deregulated deposit rate of interest will raise financial depth and eventually enhance the economic growth of Bangladesh.

Nwaeze, Michael and Nwabekee (2014) examined the impact of financial intermediation on the economic growth of Nigeria between the periods of 1992 - 2011. The empirical results of this study show that both total bank deposit and total bank credit exert a positive and significant impact on the economy.

Hossin (2015) examined the relationship between inflation and economic growth in the context of Bangladesh and found a statistically significant long-run negative association between inflation and economic growth for the country as point out by a statistically significant long-run negative relationship running from Gross Domestic Product Deflator (GDPD) to GDP.

Andabai and Tonye (2014) examined the relationship between financial intermediation and economic growth in Nigeria using data spanning (1988-2013). There is also a long-run equilibrium relationship between economic growth and financial intermediation and the result also confirms about $96 \%$ short-run adjustment speed from longrun disequilibrium.

Hossin and Islam (2019) examined the long-run equilibrium relationship between stock market development and economic growth of Bangladesh. The study demonstrated that a long-run relationship exists between stock market development and economic growth in Bangladesh. The causality test results suggest a unidirectional causality running from stock market development to economic growth.

Oleka, Sabina and Onyeze (2014) study the impact of intermediation roles of banks on the performance of the real sectors of the Nigerian economy. The study found out that banking sector intermediation has significantly improved the GDP component of the manufacturing sector, hence, has contributed marginally to the overall growth of the real sectors for sustainable development of Nigeria for the period $1992-2011$.

Sehrawat and Giri (2017) looked at the relationship between the Indian stock market and economic growth from a sectoral perspective using quarterly time-series data from 2003:Q4 to 2014:Q4. The results of the autoregressive distributed lag (ARDL) approach bounds test confirm the existence of a cointegrating relationship between sector-specific gross domestic product (GDP) and sector-specific stock indices.

Adejumo and Adejumo (2019) studied the extent to which the positive trend experienced in economic growth has translated into development in Nigeria; this is intending to ascertain the effect of growth translating into economic development. it was discovered that productivity growth contributed positively to real economic growth and negatively to nominal economic growth.

\section{Objectives}

The main objective of this research paper is to identify several factors that affect the economic development of our country. To identify also some reasons for fluctuating the economy of Bangladesh. Besides, to find out the problems associated with the gross domestic product (GDP) making components. By diagnosing the economy of Bangladesh from the viewpoint of some selected phenomena we intend to examine the relationship between GDP and some selected variables.

\section{The rationale of the Studies}

This article presents a structure to examine several sectoral growths that affect the economic development of Bangladesh. This paper set out with an analysis of the various literature on the sectoral growth and economic development nexus. This gives us an insight into the modelling of the relationship between Monetary intermediation (banks) sector (MIS), insurance sector (IS), other financial auxiliaries sector (FAS), real estate, renting and business activity sector (RBS) and Gross Domestic Product (GDP). The groundwork basis of this study is that in which sector in our country the relevant policy should be directed to boost up the economy of Bangladesh.

\section{Explanation of variables}

5.1 Gross domestic product $(G D P)$

Gross domestic product (GDP) is a monetary measure of the market value of all the final goods and services produced in a specific period. GDP (nominal) per capita does not, however, reflect differences in the cost of living and the inflation rates of the countries; therefore using a basis of GDP per capita at purchasing power parity (PPP) is arguably more useful when comparing living standards between nations, while Nominal GDP is more useful comparing national economies on the international market. 


\subsection{Financial Intermediation Sector}

\section{Financial Intermediation Sectors Covers;}

\begin{tabular}{|l|l|}
\hline $\begin{array}{l}\text { Monetary } \\
\text { intermediation } \\
\text { Sector }\end{array}$ & $\begin{array}{l}\text { This sector includes i) Bangladesh Bank ii) All scheduled \& specialized Banks iii) } \\
\text { Microfinancing Institutions including Grameen Bank, iv) Leasing \& Finance } \\
\text { companies, v) Cooperative societies including Cooperative Bank, vi) Asset } \\
\text { Management Companies, vii) Bangladesh House Building Finance Corporation } \\
\text { (BHBFC), viii) Investment Corporation of Bangladesh (ICB) and ix) Money Changers. }\end{array}$ \\
\hline $\begin{array}{l}\text { Insurance Sector } \\
\text { Other financial } \\
\text { auxiliary Sector } \\
\text { (General) including state-owned Shadharan Bima corporation and 18 life including } \\
\text { state-owned Jibon Bima Corporation. }\end{array}$ & $\begin{array}{l}\text { Other financial auxiliary sub-sector includes i) Capital market affiliates including } \\
\text { Central Depository Bangladesh Limited (CDBL), Security Exchange Commission } \\
\text { (SEC), Dhaka Stock Exchange (DSE), Chittagong Stock Exchange (CSE) and ii) others } \\
\text { including Insurance agents, Banks Association of Bangladesh (BAB), Bangladesh } \\
\text { Insurance Association (BIA), Bangladesh Leasing \& Finance Companies Association } \\
\text { (BLFCA) }\end{array}$ \\
\hline
\end{tabular}

\subsection{Monetary Intermediation:}

Production approach has been used for value-added compilation. Gross Output (GO) is measured as net interest income plus Fees \& Commissions plus other income. Finally, GVA (Gross Value Added) is measured as GO less Intermediate consumption (IC). CPI general is used for deflating to constant price.

\subsection{Insurance:}

Production approach has been used for value-added compilation. Gross Output (GO) is measured as premium received less claim paid plus other income received. Finally, GVA is measured as GO less Intermediate consumption (IC). CPI general is used for deflating to constant price.

\subsection{Other Financial Auxiliary:}

Income method i.e. cost of production method has been used for the value addition of NPIs such as SEC, BAB, BIA and BLFCA. For other products, the method has been used. Activities of the capital market (Members/ Depository participants-DPs) are measured indirectly. At first, fixed income is taken into account then variable income and margin from the total trade are estimated to get the final value-added. General Price Index of DSE is used as a deflator for capital market affiliates. On the other hand, CPI general is used as a deflator for the rest of the industries of the sub-sector.

\section{Methodology}

To cover the study the period has been taken of 23 years from FY 1996-97 to FY 2018-19. All the data have been collected from secondary sources. Most of the data have collected from different research journal, website, articles and Bangladesh Bureau of Statistics. Quantitative analysis has been done using statistical and mathematical tools such as Statistical Package for Social Science (SPSS). Useful and reliable models have been developed to analyze the data.

Dependent variable: Gross Domestic Product (GDP).

Independent variables: Monetary intermediation (banks) sector (MIS), insurance sector (IS), other financial auxiliaries sector (FAS), real estate, renting and business activity sector (RBS).

\subsection{Research model: Multivariable regression equation models.}

$$
G D P_{t}=\alpha+\beta_{1} M I S_{t}+\beta_{2} I S_{t}+\beta_{3} F A S_{t}+\beta_{4} R B S_{t}+U_{i}
$$

\subsection{Model specification:}

For empirical analysis, this study uses descriptive analysis and linear multiple regression as the underlying statistical test. A descriptive analysis of the data is conducted to obtain sample characteristics. The correlation analysis is adopted in this study to explain the association between Gross Domestic Product (GDP), and independent variables- monetary intermediation (banks) sector (MIS), insurance sector (IS), other financial auxiliaries sector (FAS), real estate renting and business activity sector (RBS). The multiple regression analysis is performed on the dependent variable GDP to test the relationship between the independent variables with the development of Bangladesh's economy (measured by GDP). 


\section{Analysis and Discussion}

7.1 Descriptive Statistics:

Table 1: Descriptive statistics of variables used in the Econometric Model

\begin{tabular}{llllll}
\hline Variables & Observation & Mean & Min & Max & Std. Deviation \\
\hline GDP & 23 & 5.9765 & 3.83 & 8.13 & 1.11907 \\
MIS & 23 & 9.5922 & -3.9 & 29.37 & 7.74262 \\
IS & 23 & 9.9970 & -2.51 & 25.22 & 7.66816 \\
FAS & 23 & 12.0065 & -2.54 & 35.29 & 9.51082 \\
RBS & 23 & 4.0039 & 3.63 & 5.15 & 0.45123 \\
\hline
\end{tabular}

Source: Results obtained (SPSS output) by the authors

The descriptive statistics of the variables both dependent and independent used in the empirical study are presented in Table 1. The mean value of GDP is 5.98\%. The mean value of the variable, monetary intermediation (banks) sector (MIS) is $9.59 \%$ with a standard deviation of $1.12 \%$. The variable "insurance sector (IS)" represents a high variability with having a mean value of $10 \%$ and a standard deviation of $7.67 \%$. The variability of "other financial auxiliaries sector (FAS)" is $9.51 \%$, which is very high. Because it's minimum value stands at $-2.54 \%$ and maximum at $35.29 \%$. And lastly the mean value of "real estate renting and business activity sector (RBS)" is $4 \%$ with the lowest standard deviation at $0.45 \%$.

\subsection{Correlation (Pearson Correlation) Matrix:}

Table- 2: Correlation Coefficients

\begin{tabular}{|c|c|c|c|c|c|c|}
\hline & & GDP & MIS & IS & FAS & RBS \\
\hline \multirow{5}{*}{ Pearson Correlation } & GDP & 1 & & & & \\
\hline & MIS & .242 & 1 & & & \\
\hline & IS & $-.505 * *$ & .104 & 1 & & \\
\hline & FAS & -.310 & -.267 & $.518 * *$ & 1 & \\
\hline & RBS & $.797 * *$ & -.008 & $-.726 * *$ & $-.358 *$ & 1 \\
\hline \multirow{5}{*}{ Sig. (1-tailed) } & GDP & 1 & & & & \\
\hline & MIS & .133 & 1 & & & \\
\hline & IS & .007 & .318 & 1 & & \\
\hline & FAS & .075 & .109 & .006 & 1 & \\
\hline & RBS & .000 & .485 & .000 & .047 & 1 \\
\hline
\end{tabular}

Source: Results obtained (SPSS output) by the authors

**Correlation is significant at the 0.01 level (1-tailed).

*Correlation is significant at the 0.05 level (1-tailed).

Table 2 is showing the correlation between the variables that are used in the model. The correlation between gross domestic product (GDP) and monetary intermediation (banks) sector (MIS) is 0.242, i.e., $(\mathrm{r}=0.242)$ which is statistically not significant. Moreover, the insurance sector (IS) has a negative correlation with GDP, $(r=-0.505)$ which is statistically significant at $1 \%$. Besides, other financial auxiliaries sector (FAS) also negatively correlated with GDP, $(\mathrm{r}=-0.310)$ and statistically not significant at $1 \%$ and $5 \%$ both. Besides, real estate renting and business activity sector $(\mathrm{RBS})$ is positively correlated with GDP, $(\mathrm{r}=0.797)$ as well as statistically significant at $1 \%$.

\subsection{Model Testing:}

Table- 3: Model Summary ${ }^{\mathrm{b}}$

\begin{tabular}{llllll}
\hline Model & $\mathrm{R}$ & R Square & Adjusted R Square & $\begin{array}{l}\text { Std. Error of the } \\
\text { Estimate }\end{array}$ & Durbin-Watson \\
\hline 1 & $.838^{\mathrm{a}}$ & .702 & .636 & .67511 & 1.037 \\
\hline
\end{tabular}

a. Predictors: (Constant), RBS, MIS, FAS, IS

b. Dependent Variable: GDP

Source: Results obtained (SPSS output) by the authors

The summary of the model is shown through the regression analysis in Table 3 . The coefficient of correlation (R) associated with the model is 0.838 , it implies that the relationship between the dependent variable (GDP) and all the independent variables-monetary intermediation (banks) sector (MIS), insurance sector (IS), other financial auxiliaries sector (FAS), real estate renting and business activity sector (RBS)-is strong. R square represents the coefficient of determination, the proportion of variance in the dependent variable which can be predicted from the independent variable, which is 0.702 and indicates that the $70.2 \%$ of the variance in GDP can be predicted from the variables-monetary intermediation (banks) sector (MIS), insurance sector (IS), other financial auxiliaries sector 
(FAS), real estate renting and business activity sector (RBS). The adjusted R-square value is 0.636 and explains that if other independent variables are incorporated in the model $63.6 \%$ of the variation in the dependent variable (GDP) can be explained by the independent variables. The standard error of the estimate, also called the root mean square error, is 0.6751 indicates that the standard deviation of the error term is $67.51 \%$. The Durbin-Watson statistic is 1.037; which falls in the range to (0-4) and less than 2 , hence, we indicate that there is a positive autocorrelation among the independent variables.

\subsection{Analysis of Variance (ANOVA):}

Table 4: Analysis of Variance

\begin{tabular}{llllll}
\hline & Sum of Squares & df & Mean Square & F & Sig. \\
\hline Regression & 19.347 & 4 & 4.837 & 10.612 & $.000^{\mathrm{a}}$ \\
Residual & 8.204 & 18 & .456 & & \\
\hline Total & 27.551 & 22 & & & \\
\hline
\end{tabular}

Source: Results obtained (SPSS output) by the authors

a. Predictors: (Constant), RBS, MIS, FAS, IS

b. Dependent Variable: GDP

Level of significance $(\alpha): 0.05$

Table 4 shows the sources of variance, regression, residual and total. The variance experienced from independent variables represented by regression partition is $19.347 \%$. And the variance which is not specified by the independent variables is taken under residual partition which is $8.204 \%$. Thus, the total variance resulting from summing up of both regression and residual is $27.551 \%$. The degree of freedom ( $\mathrm{df}$ ) for regression, calculated by total predictors including intercept minus 1 , is 4 and for residual, it is 18 which equals to the total degree of freedom minus degree of freedom for regression excluding intercept. The values of the mean square are derived from the sum of squares divided by df. The value of $\mathrm{F}$ is calculated by mean square regression divided by mean square residual and the result is 10.612, and p-value (significance) associated with this F value is zero. Since the $\mathrm{p}$-value, 0.000 is lower than the alpha value 0.05 we conclude that the independent variables reliably predict the dependent variables.

\subsection{Coefficients:}

Table- $5^{\text {a }}$ : Coefficients

\begin{tabular}{llllll}
\hline \multirow{2}{*}{ Independent variables } & \multicolumn{2}{l}{ Unstandardized Coefficients } & Standardized Coefficients $(\beta)$ & $\mathrm{t}$ & Sig. \\
\cline { 2 - 6 } & $\beta$ & Std. Error & & -1.550 & .139 \\
\hline (Constant) & -3.205 & 2.068 & .244 & 1.737 & .100 \\
MIS & .035 & .020 & .094 & .438 & .666 \\
IS & .014 & .031 & .020 & .120 & .906 \\
FAS & .002 & .019 & .874 & 4.640 & .000 \\
RBS & 2.168 & .467 & & & \\
\hline
\end{tabular}

a. Dependent Variable: GDP

Level of Significance: 0.05

Source: Results obtained (SPSS output) by the authors

The coefficients of independent variables are shown in Table 5. The value of constant, also known as Yintercept, resulting from the regression line is -3.205 which means the mean value of GDP is $-3.205 \%$ when all the independent variables have the value of 0 . The coefficient of monetary intermediation (banks) sector (MIS) is 0.035 represents that the GDP could increase by $0.035 \%$ for a one-unit increase in MIS, but it is not statistically significant at $5 \%$ level of significance $(0.10>0.05)$. Insurance sector (IS) has a coefficient of 0.014 indicates that for a one-unit increase in IS might cause to increase GDP by $0.014 \%$ which is statistically insignificant, $0.666>$ 0.05 . The coefficient of other financial auxiliaries sector (FAS) is 0.002 representing GDP might be predicted to be increased by $0.002 \%$ if FAS increased by one unit but not significant, $0.906>0.05$. The last independent variable, real estate renting and business activity sector (RBS) has a coefficient of 2.168 indicates that for a oneunit increase in RBS might cause GDP to be increased by $2.168 \%$, and it is statistically significant, $0.000001<$ 0.05 . The model stands-

$$
G D P_{\text {Predicted }}=-3.205+0.035 M I S_{t}+0.014 I S_{t}+0.002 F A S_{t}+2.168 R B S_{t}+U_{i}
$$




\section{Conclusion}

The study has examined the dynamics between financial intermediation development, real estate, rent and business activities and economic growth in Bangladesh. The results indicate that there is a presence of a significant positive relationship between real estate renting and business activity sector (RBS) indicators and economic growth and it has also a significant positive association with GDP. The analysis also shows a positive relationship among monetary intermediation (banks) sector (MIS), Insurance sector (IS), financial auxiliaries sector (FAS) and GDP. As such it was recommended that policy on financial intermediation development along with real estate, rent and business activities should be emphasizing to propel and stir up economic growth in Bangladesh.

\section{Managerial Implications}

The first major policy implication arising out of the observed findings in the article is that policymakers should concentrate mostly on real estate renting and business activity sector (RBS), as it is highly correlated with GDP. And policy should also to be formulated monetary intermediation (banks) sector (MIS), Insurance sector (IS), financial auxiliaries sector (FAS) to develop the economy of Bangladesh.

\section{Limitations and Future Research}

While conducting the study, we have faced several critical issues that limited the scope of the research to some extent. Even in the Bangladesh Bureau of Statistics (BBS), data are not at all organized. Data from BBS was extracted by searching the statistical yearbooks. Though undocumented economic activity holds a large portion of the national economy of Bangladesh, the usage of undocumented money in the Real Estate sector cannot be measured precisely because no authentic information is available anywhere.

The study is carried out based on the economy of Bangladesh by considering a few sectors. Hence, application of its outcome to other country's economy might require more research. Further study could be accomplished from the same field by the other researchers by incorporating many more sectors.

\section{Acknowledgement}

I am grateful to the anonymous referees of the journal for their extremely useful suggestions to improve the quality of the article. Usual disclaimers apply.

\section{Declaration of Conflicting Interests}

The author declared no potential conflicts of interest concerning the research, authorship and/or publication of this article.

\section{Funding}

The author received no financial support for the research, authorship and/or publication of this article.

\section{ORCID iD}

Md Shakhaowat Hossin. https://orcid.org/0000-0002-5182-7986

\section{References:}

Adejumo, A. V., \& Adejumo, O. O. (2019). Role of Productivity Growth in Economic Growth: Evidence from Nigeria (1970-2010). Global Business Review, 20(6), 13241343. https://doi.org/10.1177/0972150919848932

Andabai, P.W., \& Tonye, O. (2014). Financial Intermediation and Economic Growth in Nigeria. 1988-2013: A vector Error Correction Investigation. Mediterranean Journal of Social Sciences, 5(17):19-26.

Arabi, A. M. K. (2014). The Effect of Financial Development on Economic Growth in Sudan: Evidence.

Bencivenga, V.R., \& Smith, B.D. (1991). Financial Intermediation and Endogenous Growth. The Review of Economic Studies, 58(2), 195-209.

Demirguc-Kunt, A. \& Levine, R. (1999). Bank-based and Market-based Financial Systems: Cross country Comparisons. The World Bank.

Demirguc-Kunt, A., \& Makismovic. V. (1998). Law, Finance, and Firm Growth, Journal of Finance, 53 (6), $2107-$ 2137.

Goldsmith, R. W. (1969). Financial Structure and Development. New Haven: Yale University Press.

Greenwood, J., \& Jovanovic, B. (1990). "Financial Development, Growth, and the Distribution of Income", Journal of Political Economy. 98: 1076-1107.

Hossin, M. S. (2015). The Relationship between Inflation and Economic Growth: An Empirical Analysis from 1961 to 2013, International Journal of Economics, Finance and Management Sciences, 3(5), 426 - 434.

Hossin, M. S., and Islam, M. S. (2019). Stock Market Development and Economic Growth in Bangladesh: An Empirical Appraisal, International Journal of Economics and Financial Research, 5(11), 252-258.

Hossin, M. S. (2020). Interest Rate Deregulation, Financial Development and Economic Growth: Evidence from Bangladesh. Global Business Review. https://doi.org/10.1177/0972150920916564

Jayaratne, J., \& Strahan. P. (1996). The Finance-Growth Nexus: Evidence from Bank Branch Deregulation. 
Quarterly Journal of Economics 111, 639-670.

Levine, R. (1997). Financial Development and Economic Growth: Views and Agenda. Journal of Economic Literature, 35(2), 688-726.

Levine, R., Loayza, N., \& Beck, T. (2000). Financial Intermediation and Growth: Causality and Causes. Journal of Monetary Economics, 46, 31-77.

Madichie, C., Maduka, A., Oguanobi, C., \& Ekesiobi, C. (2014). Financial Development and Economic Growth in Nigeria: A Reconsideration of Empirical Evidence. Journal of Economics and Sustainable Development, 5, 199-208.

Mckinnon, R. (1973). Money and Capital in Economic Development, Washington, D.C.: The Brooking Institution. World Development, 2(3), 87-88.

Nissanke, M. (1991). Liberalization Experience and Structural Impediments to Savings Mobilization and Financial Intermediation. Mimeo (processed), Oxford: International Development Centre, University of Oxford.

Nwaeze, C., Michael, O., \& Nwabekee, C.E. (2014). Financial Intermediation and Economic Growth in Nigeria (1992-2011), The Macrotherno Review 3(6): 124-142.

Odedokun, M. (1998). Financial Intermediation and Economic Growth in Developing Countries. Journal of Economic Studies, 25, 203-22.

Oleka, C.D., Sabina, E.A., \& Onyeze, C.N. (2014). The Empirical Study of the Impact of Intermediation Roles of Banks on Economic Growth: A Case Study of Nigerian Experience. Humanity and social sciences Journal, 9(2), 49-60.

Onodugo, V.A., Kalu, I.E., \& Anowor, O.E. (2013). Financial Intermediation and Private Sector Investment in Nigeria. Research Journal of Finance and Accounting, 4(12):47-54.

Peia, O., \& Roszbach, K. (2013). Finance and Growth: Time Series Evidence on Causality. Available at SSRN 2206221.

Rexiang, W., \& Rathanasiri, R.A. (2011). Financial Intermediation and Economic Growth: A Lesson from Sri Lanka ICBI 2011. Faulty of Commerce and Management Studies.

Romeo-Avila, D. (2007). Finance and Growth in the EU: New Evidence from the Harmonization of the Banking Industry. Journal of Banking and Finance, 31, 1937-1954.

Rajan, R.G., \& Zingles, L. (1998). Financial Dependence and Growth. The American Economic Review, 88(3), $559-586$

Sehrawat, M., \& Giri, A. K. (2017). A Sectoral Analysis of the Role of Stock Market Development on Economic Growth: Empirical Evidence from Indian Economy. Global Business Review, 18(4), 911923. https://doi.org/10.1177/0972150917692242

Shaw, E. S. (1973). Financial deepening in economic development. Oxford University Press, New York.

Shittu, A. I. (2012). Financial intermediation and economic growth in Nigeria. British Journal of Arts and Social Sciences, 4(2), 164-179.

Uremadu, S. O., Nwokocha, A. C., \& Duru-Uremadu, C. E. (2017). Effect of Financial Intermediation and Regulations on Financial Deepening and Growth: Evidence from Nigeria. Journal on Management, 11(4). 